\title{
Metodologia uczenia operatorów robotów przemysłowych do spawania drutem litym i proszkowym
}

\author{
Approach to the methodology for training of operators \\ in GMAW and FCAW automated welding processes
}

\section{Streszczenie}

W niniejszym artykule omówione zostały etapy tworzenia technologii spawania seryjnego na przykładzie starszego typu zrobotyzowanego stanowiska spawalniczego. W przypadku spawania manualnego to technolog ustala parametry napięciowe procesu spawania, a spawacz na podstawie obserwacji wpływa na procesy cieplne spawania poprzez zmianę trajektorii ruchu. W przypadku spawania zrobotyzowanego starszymi typami robotów technolog ustala trajektorię ruchu, a operator zrobotyzowanego stanowiska spawalniczego na postawie obserwacji procesu spawania wpływa na procesy cieplne spawania. Problem jednak tkwi w tym, iż z reguły technolog nie posiada wystarczającej wiedzy na temat wpływu trajektorii ruchu końca elektrody na procesy spawania, a operator nie jest dostatecznie wyszkolony w zakresie regulacji prądem, napięciem i szybkością spawania w czasie rzeczywistym. W niniejszym artykule omówiono jak przy wykorzystaniu obrazkowej instrukcji wyjaśniającej procesy fizyczne w spawalnictwie, autorstwa Instytutu Łączenia Metali w Krakowie (Welding Journal nr 2/2016), szkolić technologów i operatorów. Przedstawione w pracy wyniki mają na celu opracowanie algorytmów do systemów wizyjnych spawania.

Słowa kluczowe: zrobotyzowany proces spawania; optymalizacja procesu spawania; opracowanie technologii spawania automatycznego; metody korekcji parametrów spawania zautomatyzowanego; spawanie; technologie; plazma

\section{Abstract}

This article presents stages for the creation of serial welding technology on the example of an older type robotized welding workstation. In case of manual welding a technologist is responsible for setting the voltage parameters of welding process while a welder during the continuous observations influences the thermal processes by modulation of motions trajectory. On the other hand, in case of welding applying the older types of robots, technologist sets the trajectory of motions, whereas the operator of the robotized workstation through the observations of the process impacts the thermal processes of welding. The problem resides in the fact that a technologist often does not resources enough knowledge concerning an impact of the end of electrode motions trajectory on the welding process effectiveness, and the operator is mostly not enough trained in a real-time regulation of welding current and travel speed. In this work we discuss the innovative methodology for training of technologists and operators with the use of a visual instruction developed by The Institute for Joining of Metals in Krakow (presented previously in Welding Journal no. $2 / 2016$ ). The aim of the presented results is a creation of the algorithms for welding visual systems.

Keywords: robotic welding process; optimization of welding process; automatic welding process technology development; methods for the correction of automated process parameters; welding; technology; plasma

\section{Wstęp}

Obecnie, gdy spawanie zrobotyzowane dysponuje czujnikami wizyjnymi i komputerową analizą obrazu z kamery [1], znajomość fizyki łuku elektrycznego i zjawisk fizycznych procesu spawania jest niezbędna do rozwijania techniki zaawansowanego spawania zrobotyzowanego, a zwłaszcza łączenia łukowego materiałów metalicznych, jak i ceramicznych. Dlatego coraz istotniejszą rolę w spawalnictwie odgrywa wyszkolenie w zakresie profesjonalnej fizyki łuku, elektroniki, elektrotermii, technologii chemicznej, a także informatyki. Zmienia się także pogląd na modelowanie fizycznych procesów spawania [1]. Pokazuje to jednocześnie interdyscyplinarność szeroko rozumianej dziedziny spawalnictwa. Za niedługo odejdzie w niepamięć wywodzące się ze spawania automatycznego pojęcie energii liniowej stosowane $w$ badaniu technologii. Pojawiają się też techniki badania spawania ręcznego. W większości przypadków spawanie można wykonać manualnie lub przy użyciu robota. Są jednak przypadki, w których człowiek nie może

Mgr inż. Ilona Jastrzębska - AGH Akademia Górniczo-Hutnicza im. Stanisława Staszica w Krakowie, mgr Marcin Głowacki - Shiloh Industries Bielsko-Biała, inż. Dariusz Cyganek - Taret Spółka z .o.o., mgr inż. Ryszard Jastrzębski - Instytut Łączenia Metali w Krakowie, mgr Dariusz Przytuła - EDAX.

Autor korespondencyjny/Corresponding author. ijastrz@agh.edu.pl 
przebywać w otoczeniu źródła ciepła np. spawanie laserem. W przypadku łączenia elementów ceramicznych metodą TIG w środowisku procesu należy wytworzyć próżnię, co powoduje, że spawanie większych elementów wymaga zastosowania robota przemysłowego. Przy ustalonych ścieżkach przejazdu robota spawalniczego, operator może założyć maskę spawalniczą i trzymając panel kontrolera w rękach, w trybie testowym może nakazać robotowi spawać, natomiast sam może obserwować zachowanie się łuku i jeziorka, ręcznie modulując prąd, napięcie i prędkość spawania.

Obecnie można zakupić symulatory spawania wyposażone $\mathrm{w}$ technologię augmented reality [1], przy pomocy których spawacz może zobaczyć wirtualny obraz obszaru spawania i na monitorze może obserwować wirtualny obraz spoiny. Tak jak w drodze do pełnego zrozumienia procesów spawania niezbędna jest szeroko pojęta obserwacja, tak w efektywnej aplikacji danego procesu niezbędna jest wiedza na bieżąco zdobywana w trakcie tej obserwacji. Dopiero przy wykorzystaniu wiedzy dotyczącej fizyki spawania, pozyskanej właśnie drogą obserwacji, możliwe jest zrozumienie i pełne wykorzystanie dostępnych środków kontroli procesu spawania, a co za tym idzie także udoskonalanie nowych rozwiązań robotów spawalniczych.

\section{Ekonomia w robotyzacji}

Tylko wtedy, gdy można zagwarantować jakość i wydajność na rynku produkcyjnym, możliwe jest zapewnienie rentowności. W obecnych czasach, kiedy przemysł spawalniczy odczuwa duży brak siły roboczej, inwestowanie w nowej generacji spawanie zrobotyzowane może zapewnić dobrą jakość oraz wysoką wydajność produkcji. Spawanie zrobotyzowane $z$ wykorzystaniem zaawansowanych systemów wizualnych $[2 \div 5]$ pozwala na spawanie mniej dokładnych wymiarów w seryjnych ilościach, a więc produkowanie tańszych elementów.

Jednakże niektóre firmy nie chcąc podjąć zbyt dużego ryzyka finansowego, nie inwestują w zakup kosztownych nowych robotów spawalniczych. W związku z tym uzasadnionym jest dobre wykorzystanie tańszych, starszych typów robotów spawalniczych. Tego typu roboty nie spełniają wymaganego standardu nowej generacji robotów spawalniczych. W celu zaspokojenia popytu na wysoką jakość i wydajność, operator może zostać odpowiednio przeszkolony do obserwacji procesu spawania zrobotyzowanego i korekty parametrów w czasie rzeczywistym. To znaczy, że operator będzie potrafił w czasie zrobotyzowanego spawania, jeśli zajdzie taka potrzeba, regulować napięcie, prąd i prędkość spawania w celu minimalizacji wad produkcyjnych. Takie rozwiązanie zapewniłoby większą produktywność procesu spawania, ponieważ ruchy robota pomiędzy wykonywanymi poszczególnymi spoinami są wykonywane szybciej, niż jakikolwiek wykwalifikowany spawacz potrafi. W dodatku to rozwiązanie może obniżyć koszty produkcji jednostkowej.

Wykonywanie połączeń spawanych manualnie $\mathrm{w}$ wielu przypadkach jest nieopłacalne lub wręcz niemożliwe. W sytuacji, gdy do wyprodukowania są duże partie powtarzających się elementów, zastąpienie spawania manualnego przez automatyzację procesu znacząco obniża koszty produkcji, stabilizuje proces oraz redukuje ilość możliwych błędów w procesie. Nierzadko również, jak w przypadku spawania TIG wielkogabarytowych elementów z materiałów wymagających wytworzenia w obszarze łączenia próżni czy też spawania laserowego, obecność spawacza może być wyłącznie zdalna, co wymaga użycia robota przemysłowego.

Korzyści płynące z automatyzacji procesu spawania są powszechnie znane, wśród nich na potrzeby niniejszego artykułu warto przywołać takie jak: możliwość prowadzenia symulacji off-line celem maksymalizacji wydajności i minimalizacji kosztów procesu, możliwość nadzorowania szerszego względem manualnego spawania spektrum zmiennych parametrów procesu (kąty, prędkości, odległości palnika od spawanych elementów itd.), a także gromadzenie i analizowanie znacznie bogatszej ilości danych wejściowych.

Mówiąc o korzyściach płynących z automatyzacji spawania, warto zaznaczyć, że są również koszty, które trzeba ponosić. Zarówno dodatkowe koszty drogich narzędzi i mocowań pozycjonujących elementy spawane do aplikacji zrobotyzowanych, także wzrastające wraz z postępującym wiekiem sprzętu koszty jego serwisu i napraw oraz inne. Kiedy sprzęt jest jeszcze nowy, stosunkowo rzadko zawodzi i pozwala przede wszystkim skupić się na korzyściach z niego płynących. Niemniej jak w zakładach produkcyjnych, które funkcjonują od wielu lat w oparciu o automatyzację procesów spawania lub w nowo powstających przedsiębiorstwach, których nie stać na zakup nowych sprzętów, do produkcji używane są roboty przemysłowe z dużymi przebiegami, sięgającymi setek tysięcy roboczo-godzin. Taki sprzęt nie funkcjonuje tak sprawnie jak nowy. Precyzja, a przede wszystkim powtarzalność manipulatora jest mniej doskonała niż dwie dekady temu, gdy był on instalowany na linii montażowej. Starsze generacje robotów nie posiadają zaawansowanych technologicznie narzędzi jak np.: moduły śledzenia rowka spawalniczego, auto-kalibracja itp. jednakże nadal produkują i „zarabiają", a jedyne czego potrzebują to dobrze wykwalifikowany personel, który w osobie operatora będzie prowadził proces oraz technologię spawania, na której będzie bazował.

Z tych względów, bardzo ważnym elementem w trakcie przygotowywania się do podjęcia nowego projektu jest rozpoznanie tzw. wykonalności, tzn. określenie czy dysponujemy potrzebnym sprzętem, zasobami do produkcji danego elementu, czy jesteśmy w stanie spełnić wymagania stawiane przez klienta i czy na końcu tej drogi jest pewność, że otrzymany wyrób będzie zgodny i spełniający swoje zadanie. Gdy projekt przejdzie do fazy prototypowania (o ile taka wystąpi), powstaną wówczas pierwsze dokumentacje pWPS (pWPS, ang. Prequalified Welding Procedure Specification), w oparciu o które możliwe będzie $w$ trakcie wdrażania docelowych narzędzi i sprzętu tworzenie właściwej technologii spawania. Różnice w późniejszej dokumentacji pWPS będą wynikały przede wszystkim z tego, iż mimo posiadania takich danych wejściowych jak materiały do spawania, ilość wprowadzonego ciepła do złącza $(\mathrm{kJ} / \mathrm{mm})$ już w fazie przygotowania, to dopiero od wykonywania pierwszych sztuk na docelowej konstrukcji narzędzi pozycjonujących, umożliwiających lub nierzadko utrudniających dostęp do złączy, będzie można dokładnie określić pozycje i kąty palnika, stick-out (a więc również długość łuku), prędkości i inne fizyczne zmienne procesu spawania. W tym miejscu należy zaznaczyć, że właśnie dlatego bardzo ważne jest opracowywanie docelowej technologii procesu spawania na zasadach zawartych w normie ISO 15613: - Specyfikacja i kwalifikowanie technologii spawania metali - Kwalifikowanie na podstawie przedprodukcyjnego badania spawania/zgrzewania, a nie inną z tej rodziny, gdyż ta jako jedyna oddaje pełne realia procesu spawania zautomatyzowanego i tym samym pozwala właściwie walidować proces.

Oczywiście należy wspomnieć też znane i stosowane, przede wszystkim w branży automotive, programy do symulacji procesu spawania (zgrzewania, klejenia itd.). Dostarczają one wielu hipotetycznych danych. Jednakże z jednej strony nie są to programy tanie i szeroko dostępne, a z drugiej w dużej mierze te teoretyczne wyliczenia przy przełożeniu na praktykę wymagają korekt.

Cena nowego robota przemysłowego z kontrolerem wizyjnym to koszt do 90000 \$ USA, a cena starego robo- 
ta (o przebiegu od 10000 do 15000 godzin pracy) wynosi od 4000 do 15000 \$ USA. Na potrzeby skrótowego zobrazowania powyższego twierdzenia załóżmy, że koszt zatrudnienia profesjonalnego spawacza dla firmy produkcyjnej to kwota rzędu 7000 PLN miesięcznie, natomiast koszt wykwalifikowanego operatora stanowiska zrobotyzowanego wynosi 3700 PLN. Przy poniesionych nakładach na zakup, transport, integrację i uruchomienie stanowiska zrobotyzowanego w wysokości 50000 PLN zwrot inwestycji powinien nastąpić w ciągu 15 miesięcy. Do tych założeń należałoby doliczyć zyski pośrednie, wynikające ze wzrostu wydajności operacji, 20-30\%, (w zależności od długości i liczby spoin, długości przejazdów jałowych i gabarytów spawanych elementów), a także ze zmniejszenia kosztów złej jakości dzięki rozbudowanej możliwości kontroli procesu oraz zapewnieniu jego znacznie lepszej powtarzalności.

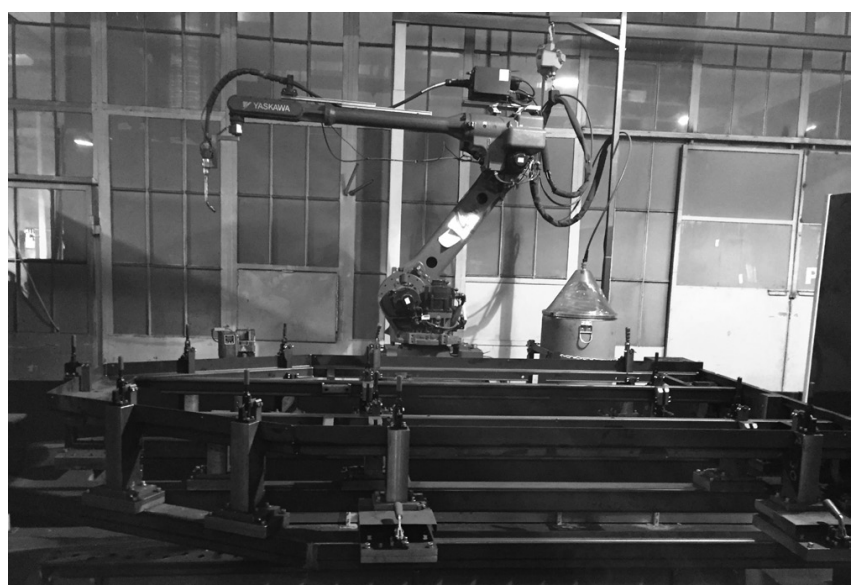

Rys. 1. Stanowisko zrobotyzowanego spawania przyczep samochodowych (Taret Spółka z o.o.)

Fig. 1. Robotized workstation for welding of car trailers (Taret Spółka z o.o)

\section{Metodyka działania operatora zrobotyzowanego procesu spawania MAG}

Zaawansowane systemy obsługi zrobotyzowanych stanowisk, umożliwiające symulacje na modelach, programowanie off-line, szybkie kalibrowanie punktów TCP i wiele innych udogodnień w ostatnich latach zostały prężnie rozpowszechnione w Europie, a ich rozwój jest wyjątkowo prężny. Jednakże, nie należy zapominać, że roboty w spawalnictwie są obecne dopiero od kilku dekad i to właśnie te pierwsze generacje stanowią znaczną część funkcjonujących obecnie w przemyśle stanowisk produkcyjnych. Z tego też względu to właśnie praca operacyjna na takim stanowisku posłuży jako przykład metodyki działania operatora. Pracując na starszego typu sprzęcie (np. Motoman XRC, MRC, ABB irb 1400 itp. bez korzystania z programów do symulacji), metodykę pracy należy podzielić na dwa etapy:

- - opracowanie szeroko rozumianej technologii spawania danych elementów w celu wystawienia pierwszej poprawnej dokumentacji pWPS, ale przede wszystkim celem przełożenia wcześniejszych założeń ekonomiki

- i opłacalności projektu na warunki rzeczywiste,

- optymalizacja procesu i nadzór nad parametrami maszyny o sześciu stopniach swobody.

W trakcie ustalania parametrów pWPS dla konkretnych złączy spawanych metodą MAG, należy prowadzić pracę w sposób zależny bezpośrednio od charakteru elementu spawanego, zamieszczając w procedurze spawania informacje ważne z punktu widzenia produkcji seryjnej i automatyzacji. Zasadniczo są dwa przypadki, które należy wziąć pod uwagę tj. czy większą trudnością będzie (1) uzyskanie zgodnych charakterystyk wymiarowych spawanego elementu czy (2) technologicznej poprawności złączy.

(1) W przypadku, gdy większą trudność w uzyskaniu wyrobu zgodnego stanowić będzie utrzymanie wymagań wymiarowych, a spawane materiały będą łatwo spawalne, a złącza dostępne i proste, należy w trakcie opracowywania procedury skupić się przede wszystkim na ilości i miejscu wprowadzanego ciepła, etapowaniu spoin, etapowaniu złączy, zwiększaniu bądź zmniejszaniu w ramach dozwolonego zakresu zawartego w dokumentacji WPQR (ang. Welding Procedure Qualification Record) ilości wprowadzanego ciepła (energii liniowej) w danym fragmencie na długości złącza, nakładaniu napoin/spoin kontrujących odkształcenia itp. W razie poważnych problemów z odkształceniami, gdy energia liniowa spawania nie może być niższa i odkształcenia są nieuniknione, można zastosować zmiany w kształcie komponentów wchodzących do procesu lub pozycji ich bazowania przed spawaniem, tak aby po spawaniu zapewnić tolerancje wymiarowe poprzez statystyczne wyliczenie wymaganej odchyłki.

(2) Z kolei w sytuacji, kiedy większą trudność stanowić będzie uzyskanie poprawności technologicznej złącza, czyli takiej, gdzie wszystkie wymagane badania niszczące i nieniszczące pozwolą zatwierdzić WPQR, należy się skoncentrować na innych zmiennych wchodzących do procesu. Jest to sytuacja, w której trudności procesowe wynikać mogą ze składu chemicznego spawanego materiału lub precyzji wcześniej przygotowywanych elementów do spawania (np. poszarpana krawędź przy złączach kątowych, zmiany na obrysie elementów spawanych doczołowo). Znaczna część tego typu problemów może być wyeliminowana już na etapie oceny ryzyka i skutków przy użyciu analizy DFMEA (ang. Design Failure Mode and Effects Analysis).

Przy opracowywaniu dokumentacji WPS w pierwszym przypadku należy przede wszystkim wziąć pod uwagę zakres, w jakim złącze będzie poprawnie wykonane, a jednocześnie umożliwi wprowadzać zmiany w ramach obowiązujących tolerancji w celu uzyskania oczekiwanej poprawności wymiarowej. Chodzi w szczególności o zwrócenie uwagi i stworzenie zapisu informacji dotyczącej kąta prowadzenia palnika i dokładnej pozycji jego przejazdu, a także zmiennych prędkości przejazdu. Pozwoli to w przypadku wystąpienia ew. zakłóceń $\mathrm{w}$ procesie na dokładnie odtworzenie lub poprawę wybranych wielkości, a także takie „ustawienie procesu", aby kontrolować wybrane charakterystyki spoiny i poprzez to nie wpływać na zgodność wymiarową spawanego elementu. Dla przykładu, aby zapewnić montowalność wspornika mocującego kanapę pasażerską do stelaża w kabinie samochodu typu van, produkowanego dla jednego z czołowych producentów siedzeń samochodowych, należało połączyć elementy tłoczone ze stali S420 o grubości 2,5 mm i zmieścić pierwotnie założoną spoinę pachwinową a2, gdzie dla jednego z wymiarów "z" ilość przewidzianego miejsca nie przekraczała $1,8 \mathrm{~mm}$. W celu uzyskania zamierzonego złącza należało nadać mu asymetryczne rozłożenie poprzez prowadzenie palnika zmodyfikowane o wymagane przesunięcie spoiny oraz zmniejszyć wysokość właściwą spoiny do 1,3 mm - 1,7 mm. Aby operatorustawiacz wiedział jak to osiągnąć, należało załączyć w dokumentacji WPS informację o przesunięciu końca elektrody od grani spoiny o zadaną wielkość oraz ustawieniu kąta palnika tak, aby wtopienie w grani było osiągnięte oraz wymiar "z" nieprzekroczony. Opisane studium przypadku zostało przedstawiony na rysunku 2.

Gdy problemem nie są wymiary, elementy spawane są wielkogabarytowe i grubościenne, a występują problemy natury technologicznej (wynikające z wymagań mechanicznych 
czy wizualnych, np. brak udarności, przyklejenia itp.) należy wówczas tak dobierać parametry, aby na przewidywane z tolerancji zmienne charakterystyki wymiarowe wchodzących do procesu komponentów, proces technologiczny był „odporny" i umożliwiał ich poprawne łączenie. Dla przykładu, gdy krawędzie elementów wchodzących do spawania złączy kątowych pozostawiają szczeliny o różnych odstępach, należy tak programować układanie ściegu spoiny, aby był on dostatecznie uniwersalnie ulokowany, wielkość jeziorka kompensowała te różnice itp. Przy dużych szczelinach między elementami cienkościennymi dla połączeń ze spoinami pachwinowymi konieczne są przesunięcia końca elektrody na blachę poziomą w celu uniknięcia przepaleń lub w przypadku blach grubych, w środek powstałej szczeliny, aby zapobiec powstaniu przyklejeń w grani.

Meritum poruszanej problematyki jest fakt, iż w wielu przypadkach do utworzenia lub odtworzenia poprawnego połączenia potrzebne są informacje, które nierzadko nie są zawierane w dokumentacji WPS przekazywanej na produkcję seryjną, a operator procesu nie mając kompletnej informacji bazuje na obserwacji procesu w czasie rzeczywistym procesu spawania i dedukuje na nowo sprawdzone przy pWPS rozwiązania. Dlatego, kompletność informacji jest tak istotna z punktu widzenia zarówno jakości, ekonomiki, jak i powodzenia samego zautomatyzowanego procesu spawania.

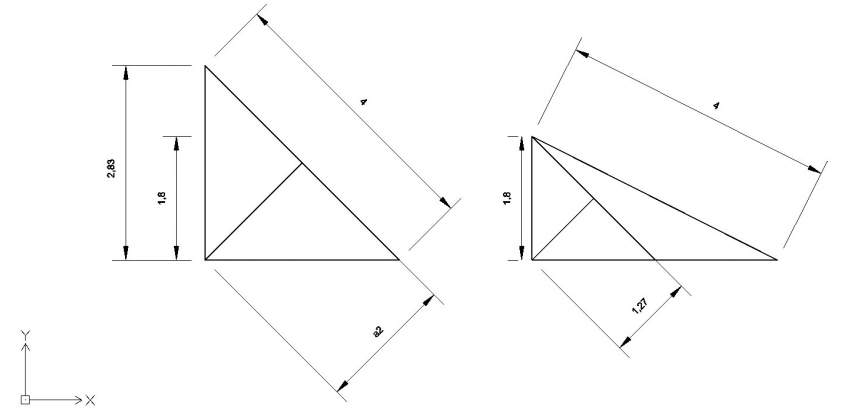

Rys. 2. Przesunięcie końca elektrody od grani spoiny o zadaną wielkość oraz ustawienie kąta palnika tak, aby zarówno wtopienie w grani było osiągnięte i wymiar "z" nieprzekroczony

Fig. 2. Shift of the end of the electrode from the weld root and setting of the angle for a better penetration and achieving an appropriate dimension of the joint

\section{Kontrola i nadzór nad parametrami zrobotyzowanego spawania}

Kolejny etap, tj. kontrola i nadzór nad parametrami procesu spawania nie jest wyłącznie skierowany na utrzymanie poprawności przebiegu procesu. Polega on na metodycznym korygowaniu i polepszaniu wyników spawania. Nierzadko założenia teoretyczne są takie, że technologia, która opuszcza dział B\&R jest doskonała, pozwalająca uzyskać optymalne wyniki zarówno ekonomiczne, jak i jakościowe. Rzeczywistość jednak jest taka, że czasu na drobne zmiany jest zbyt mało lub wcale. Dlatego też to właśnie w drugim etapie metodyki działania na zrobotyzowanym stanowisku spawania, prowadzone są korekty parametrów w celu osiągnięcia mniejszej ilości rozprysków, aby operator zrobotyzowanego procesu nie musiał poświęcać zbyt dużo czasu na oczyszczanie detali, uzyskanie gładszego lica spoiny czy mniejszego odkształcenia kątowego, aby wskaźniki statystycznej kontroli procesu SPC (ang. Statistical Proces Control) dla konkretnych wielkości służących do opisu złącza były bliżej nominalnej wartości, a rozrzut na wykresie jak najmniejszy. Wszystko w ramach obowiązującej technologii lub celem wystawienia nowej - lepszej. Stąd szybka obserwacja: wszystkie te działania są przede wszystkim nastawione na zysk.

Jak wygląda to w praktyce, najlepiej pokazują przykłady spawania różnych wsporników i łączników konstrukcji w przemyśle samochodowym, w zakładzie produkcyjnym poziomu Tier1 lub Tier2. Łączenie prostej konstrukcji z tłoczonych elementów, stali S420 MC, grubości ścianek $2 \mathrm{~mm}$, złącze zakładkowe, spoina układana po okręgu o promieniu $25 \mathrm{~mm}$. W tym miejscu jest już wiadomo, że robot może mieć problem ze zmieszczeniem palnika wśród wszystkich docisków i elementów bazujących detal. Kąty pochylenia palnika będą tutaj odgrywały największe znaczenie w związku z wymaganą wysokością nadlewu lica. Operator w takim przypadku musi tak ustawiać parametry spawania, aby z jednej strony zminimalizować ilość rozprysków, a z drugiej uzyskać pewne wtopienie w obie ścianki i jednocześnie nie przesadzić. Ponadto, operator musi zwrócić uwagę, aby zbyt duży prąd nie powodował przepalenia ścianek detalu. Stosując konwencjonalne źródło mocy, parametry spawania ustala się $w$ kierunku natryskowego przenoszenia kropli ciekłego metalu, czyli ustawia się wysokie napięcie i prąd, w celu eliminacji rozprysków i zbyt wypukłego lica spoiny. Następnie parametry równoważone są prędkością przejazdu, aby materiał nie zdążył się nagrzać na tyle, by po drugiej stronie zaczęły wychodzić przepalenia, ani aby podłoże nie "nabrało" zbyt dużej adhezji względem rozprysków. Kolejną kwestią jest wkładanie drutu w odpowiednie miejsce jeziorka spawalniczego w ten sposób, aby zimna kropla skutecznie studziła jeziorko, tam gdzie należy zwolnić, a tam gdzie należy przyspieszyć zapewnienie wymaganego głębokiego wtopienia materiału podstawowego poprzez prowadzenie łuku na początku jeziorka. Dużą rolę $w$ tym przypadku odgrywa kąt palnika i kierunek jego przesuwu. Na potrzeby spawania tego detalu, względnie cienkościennego, najlepszym rozwiązaniem jest pchanie drutu przed palnikiem. Kąty wymuszane są przede wszystkim dostępem do złącza, a więc są ograniczone i muszą być traktowane wtórnie, nie mniej niż $45^{\circ}$. Operator widząc na bieżąco efekty swojej pracy, jest w stanie regulować napięcie i posuw drutu, dążąc do szybkiego uzyskania parametrów spawania o zadowalającym efekcie i ograniczając ilość Jobów w programie robota do minimum.

Innym przykładem działania operatora przy optymalizowaniu parametrów spawania jest spawanie wspornika do samochodu ciężarowego, grubszej konstrukcji, ceownik o wymiarach głównych $250 \mathrm{~mm}$ x $250 \mathrm{~mm}$ spawany do płaskownika o wymiarach $300 \mathrm{~mm}$ x $250 \mathrm{~mm}$, tym razem materiał jeszcze "wdzięczniejszy” do spawania, bo ze stali S355 JR o grubości kolejno $8 \mathrm{~mm}$ i $10 \mathrm{~mm}$. Spawanie takiego elementu wydawałoby się wręcz idealne w swej prostocie, lecz gdy pod uwagę weźmie się wymagania odnośnie zabezpieczenia otworów montażowych w spawanych elementach i przez to utrudniony dostęp do całości złącza, a także wymóg spawania po całej wewnętrznej długości ścianki ceownika, przy zachowaniu bardzo restrykcyjnych obostrzeń dotyczących wymiaru „z" spoiny pachwinowej, zadanie to okazuje się znacząco utrudnione. Dodatkowo, zawsze należy doliczyć odchyłkę od nominalnie zadanej ścieżki przejazdu palnika z każdym kolejnym spawanym elementem. Rozwiązanie jest takie, że narzędzie, w którym pozycjonowany jest detal, umożliwia przejazd w pozycji PA po dłuższej ściance detalu, a dwie krótsze spawać można już tylko w pozycji PB. Wymaga to płynnego przejścia zarówno pozycji palnika spawającego, lawirującego między dociskami i osłonami na spawanym elemencie, jak również płynnego obrotu pozycjonera o trzech osiach swobody. Spawając w pozycji PB, prąd spawania jest w zakresie $250 \mathrm{~A}-300 \mathrm{~A}$ i jest zadany w jednym Jobie prądowym, więc 
to prędkości przejazdu są tutaj kluczową kwestią wpływającą na poszczególnych milimetrach spoiny o jej kształcie. Operator widząc efekty bezzwarciowego przejścia kropli w łuku, musi postarać się przede wszystkim, aby w trakcie przejścia z jednej pozycji spawania do drugiej, robot nie powodował powstania podtopień. Należy w takim przypadku zapewnić przejście ze spawania płynnie pchanym drutem do spawania drutem ciągnionym, zmieniając pozycje początkowo w PB, a następnie na krótki czas w PA. To działanie pozwala palnikowi "uciec" z nadwyżką materiału w rogu ceownika i nie zwiększyć wypukłości lica.

Działając w zakresie dozwolonych odchyłek od ustalonej energii liniowej spawania w określonej technologii, ustawiane złącze można wykonać na wiele sposobów, szczególnie gdy ma się do dyspozycji bardziej zaawansowane źródła prądowe, wyposażone w moduł pozwalający spawać z użyciem niskoenergetycznego procesu spawania. Szereg dodatkowych ustawień takich jak długość łuku czy dynamika przenoszenia kropli jest dostępnych w tracie kontrolowania procesu. Dzięki tym dodatkowym ustawieniom spawacz może dowolnie wręcz formować kształt ściegu, znacząco kompensując ograniczenia omówione powyżej. Za przykład można podać spawanie wspornika, w uproszczeniu dwuteownika, o grubości ścianki 1,5 mm, o bardzo restrykcyjnych wymaganiach rysunkowych i tolerancjach ogólnych rzędu $+/-0,1 \mathrm{~mm}$. Problem stanowią tutaj krawędzie, które cięte na prasie są poszarpane i nierówne, prowadząc do powstania dużych odstępów w grani spoiny pachwinowej. Drugim znaczącym utrudnieniem do wykonania żądanego złącza jest znacznie ograniczona przestrzeń na nadlew lica i konstrukcyjnie wymuszona asymetria złącza. Spoina w klasie jakości B, zgodnie z PN-EN ISO 5817, może być w takich warunkach uzyskana wyłącznie dzięki korekcji głębokości wtopienia, wielkości kropli i szerokości strumienia, w jakim jest przenoszona. Materiał dodatkowy musi być przenoszony bardzo szeroko, jednocześnie drut musi trafiać na początek jeziorka. W tym przypadku największym wyzwaniem jest uzyskanie wtopienia, zważywszy na niekorzystną asymetrię spowodowaną brakiem miejsca na pełnowymiarową długość wymiaru "z" spoiny i wspomniany odstęp w grani. Mimo iż nowoczesne źródła prądowe znacznie częściej czerpią korzyści z pionowego prowadzenia palnika, w tym przypadku należy palnik pochylić około $20^{\circ} \mathrm{w}$ przeciwnym kierunku do przejazdu, drut skierować $2 \mathrm{~mm}$ poniżej środka złącza i oczywiście należy uruchomić spawanie pulsacyjne. Użycie konwencjonalnego źródła prądowego nie pozwoliło na spełnienie wszystkich wymagań klienta i dopiero inwestycja w nowe technologie pozwoliła w warunkach produkcyjnych ustabilizować proces.

\section{Wpływ własności żużla na technikę spawania drutem proszkowym}

W pracy [5] omówiono zagadnienia związane z żużlami drutu proszkowego i elektrod otulonych. Spawanie drutem proszkowym nie wymaga spawarki impulsowej przy spawaniu stali austenitycznych, a parametry spawania są takie same jak przy spawaniu stali czarnej.

Podstawowym błędem przy wprowadzaniu spawania drutem proszkowym jest bezmyślne przenoszenie doświadczeń ze spawania elektrodą otuloną. Jak pokazuje rysunek 3 , skojarzenia powinny być odwrotne, to znaczy drut proszkowy rutylowy w miejsce elektrody zasadowej.

Żużel "długi" daje dużą dowolność w wykonywaniu ruchów podczas wypełnienia i pozwala kształtować grubość układanej warstwy od $1 \mathrm{~mm}$ do $5 \mathrm{~mm}$ (kombinacja ruchów łukowych do góry z ruchami zygzakowatymi i łukowymi do dołu) [1].
O typie ruchów zakosowych decyduje też efekt zaciskania łuku elektrody zasadowej i efekt zaciskania łuku drutu proszkowego rutylowego [1]. Jeżeli rdzeń elektrody topi się szybciej niż otulina, to łuk elektryczny jest zawężany przez "dyszę otuliny". Jeżeli wypełnienie rutylowe drutu proszkowego zgazowuje szybciej od topienia rurki metalowej, to łuk jest zaciskany i mocniej odsuwa żużel. W efekcie przy spawaniu warstwy przetopowej na ogniotrwałej podkładce ceramicznej wykonuje się ruchy takie jak przy spawaniu elektrodą zasadową. Należy też pamiętać, że skład chemiczny i fazowy żużla drutu proszkowego znacznie różni się od składu żużla elektrody zasadowej, co przedstawiono w pracach [6-8]. Wpływa to jednocześnie na temperaturę mięknięcia żużla (tj. momentu pojawiania się pierwszej ilości fazy ciekłej) i zakres temperatur od tego punktu do całkowitego stopienia. Badania te pozwoliły ustalić zakres temperaturowy topnienia/krzepnięcia żużli, otrzymanych po spawaniu różnymi typami elektrod. W pracy [6] wykazano, iż żużle elektrod rutylowych wykazują znacznie większą różnicę temperatur pomiędzy początkiem mięknięcia a całkowitym stopieniem niż żużle elektrod zasadowych. Z kolei, żużel drutu proszkowego wykazuje najwyższą temperaturą mięknięcia i topienia oraz niski zakres temperatur pomiędzy nimi, co powoduje, że szybciej krzepnie (tzw. żużel „krótki”). Dzięki temu spawanie w trudnych pozycjach takich jak pułapowa i pionowa jest znacznie łatwiejsze z użyciem drutu proszkowego.

Przy wdrażaniu technologii spawania drutem proszkowym należy pamiętać, aby wolny wylot elektrody był $2 x$ dłuższy od tego, który stosujemy przy spawaniu drutem litym. Zapewnia to przetopienie proszku ciepłem oporowym i otrzymanie spoiny wolnej od żużli. Z tego względu metoda spawania drutem proszkowym jest idealna do wykonywania złącz teowych na 1/2 V. Ze względu na duży wolny wylot elektrody napięcie przy drucie o średnicy $1,2 \mathrm{~mm}$ powinno wynosić $23 \mathrm{~V} \div 24 \mathrm{~V}$, a prąd powinien być w zakresie $180 \mathrm{~A} \div 250 \mathrm{~A}$. Przy większym prądzie w spoinie powstaną pory.

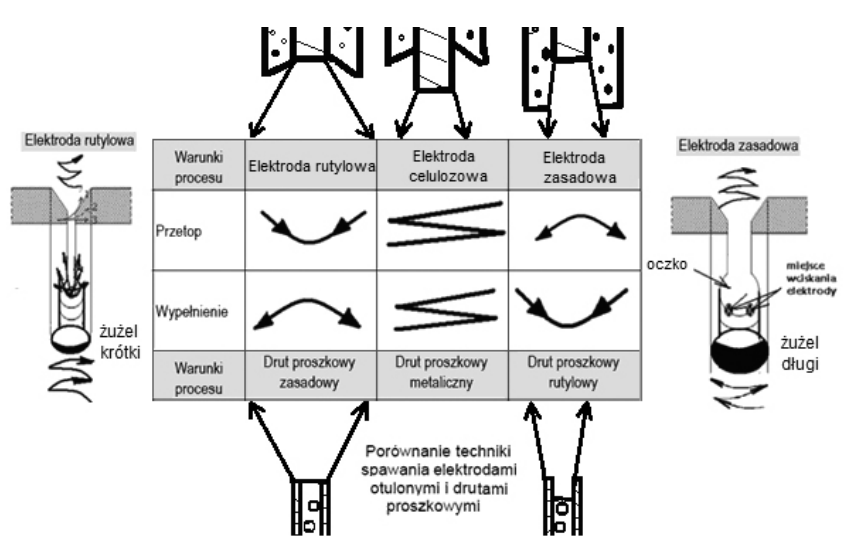

Rys. 3. Wpływ własności żużla na technikę spawania [2]

Fig. 3. Influence of the slag properties on the welding technique [2]

\section{Podstawy fizyczne szkolenia operatorów robotów}

Na rysunku 4 przedstawiono polski plakat wykorzystywany w Arizona Western College Ernest Lopez Welding Institute do nauki programowania robotów [9]. Przykłady wyjaśnienia istotnych zagadnień procesów fizycznych podczas spawania przedstawione w sposób wizualny są dobrym narzędziem do nauki dla programistów (dobór trajektorii ruchu), a także operatorów robotów spawalniczych (korekta w czasie rzeczywistym prądu napięcia i szybkości spawania). 


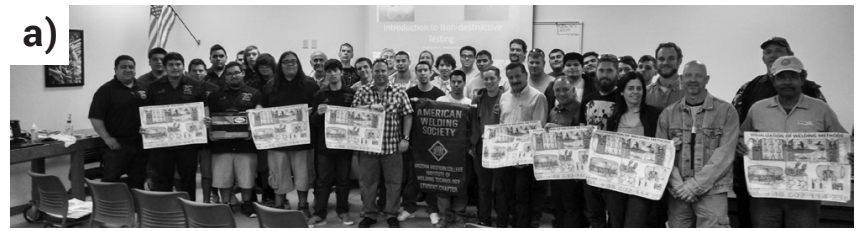

b) VISUALIZATION OF WELDING METHODS

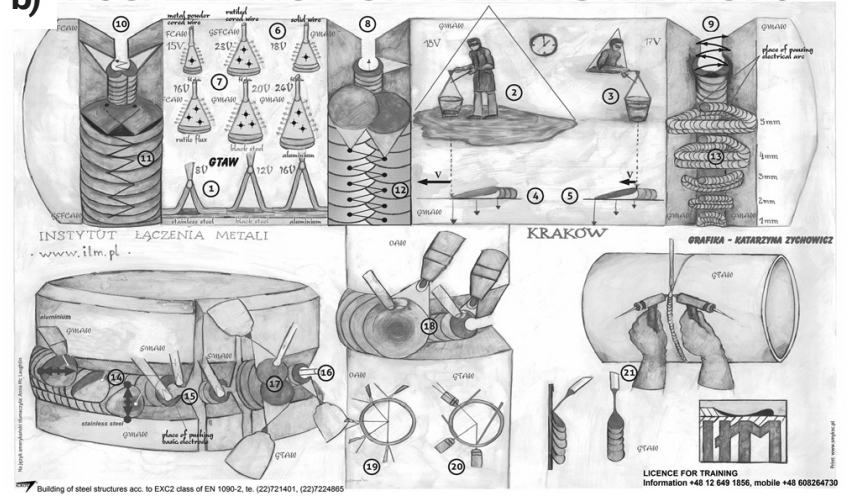

Rys. 4. Fotografia a) członków Amerykańskiego Stowarzyszenia Spawalniczego (American Welding Society) USA, Arizona Western College Institute of Welding Technology, z polskimi plakatami do nauki operatorów robotów spawalniczych (Welding Journal 2/2016 [9]); b) plakat do nauki operatorów robotów spawalniczych opracowany przez Instytut Łączenia Metali w Krakowie

Fig. 4. Photography a) of members of the American Welding Society USA, Arizona Western College Institute of Welding Technology, with polish posters (Welding Journal 2/2016 [9]); b) Polish posters developed as a visual aid for welding and training of robotic welding operators, by Institute for Joining of Metals in Cracow

W Przeglądzie Spawalnictwa nr 1/2016 [1] przy okazji omawiania inteligentnej maski spawalniczej omówiliśmy kilka przykładów z plakatu przedstawionego na rysunku 4 [9].
Przykłady (11) i (12) na rysunku 4b wyjaśniają podstawową różnicę w spawaniu drutem proszkowym i drutem litym. Ponieważ drut proszkowy zapewnia uzyskanie szerokiego łuku i dużego jeziorka spawalniczego w porównaniu z drutem litym (6 napięcie drutu proszkowego $23 \mathrm{~V}$ a drutu litego $18 \mathrm{~V}$ ), to aby nagrzać podłoże do temperatury zwilżalności, nie trzeba przytrzymywać elektrody po bokach i należy wykonywać $3 x$ szybsze ruchy poprzeczne niż w przypadku spawania drutem litym. Przykład (14) pokazuje, że drutem litym aluminium spawamy metodą $w$ lewo (tzn. metodą pchania), natomiast drutem proszkowym stal nierdzewną należy spawać metodą w prawo (tzn. metodą ciągnięcia). W przypadku spawania rur prostymi ściegami, ponieważ rurka topi się szybciej niż drut lity, prędkość spawania musi być znacznie większa. Przykłady (4) i (5) demonstrują, iż zwiększając prędkość spawania, przesuwamy proporcję pomiędzy energią topienia a energią grzania jeziorka w kierunku zwiększenia głębokości wtopienia i obniżenia temperatury jeziorka ciepłem topienia. Dlatego, jak wynika z przykładu (7), po zwiększeniu prędkości spawania, należy zwiększyć także napięcie. Przykłady (2) i (3) tłumaczą, iż obniżając napięcie, zwiększa się głębokość wtopienia i obniża się temperatura jeziorka spawalniczego. Jak wynika z pracy [3], aby nie doprowadzić do zmiany głębokości wtopienia przy zwiększaniu prędkości spawania, należy nie zmieniać proporcji pomiędzy prędkością podawania drutu a prędkością spawania. Dodatkowo, szybsze topienie rurki i szybsze topienie proszku, wynikające z dwukrotnie dłuższego wolnego wylotu elektrody, obniża temperaturę jeziorka na tyle, że spoina ze stali austenitycznej jest "biała”, a nie "czarna" (co byłoby efektem przegrzania spoiny austenitycznej). Większy prąd spawania podczas spawania w pozycji pionowej i sufitowej drutem proszkowym i większa szybkość topienia rurki wymagają również większej prędkości spawania.

\section{Wnioski}

- Starsze generacje robotów nie posiadają zaawansowanych technologicznie narzędzi, jednakże nadal produkują i „zarabiają”, a jedyne czego potrzebują to dobrze wykwalifikowany personel, który w osobie operatora będzie prowadził proces oraz technologię spawania.

- W zakładach produkcyjnych, które funkcjonują od wielu lat w oparciu o automatyzację procesów spawania lub w nowo powstających przedsiębiorstwach, których nie stać na zakup nowoczesnych drogich stanowisk automatycznych i do produkcji używane są roboty przemysłowe, zatrudnienie operatora jest opłacalne.

- Wyposażenie operatora zrobotyzowanego stanowiska spawalniczego w komputerowe wzbogacone przetwarzanie obrazu z kamery umożliwia zastosowanie omówionej w niniejszym artykule fızyki spawania.

- Wykorzystanie fizyki spawania łukowego jest niezbędne do automatycznego doboru przez robota techniki spawania.

Autorzy dziękują pracownikom firmy SPAW-PROJEKT Kraków za cenne uwagi dotyczące praktycznych aspektów związanych z nowymi technologiami w spawalnictwie.

\section{Literatura}

[1] R. Tadeusiewicz, I. Jastrzębska, R. Jastrzębski: Możliwości stworzenia maski spawalniczej z komputerowym przetwarzaniem obrazu zamiast filtrów spa-

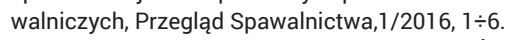

[2] R. Jastrzębski, J. Mikuła, M. Skarpetowski, J. Żurek: Porównanie techniki spawania elektrodami otulonymiz drutami proszkowymi rutylowymi i zasadowy-

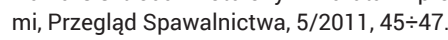

[3] M. Yang, Z. Yang, B. Cong, B. Qi: A study on the surface depression of the molten pool with pulsed welding, Welding Journal, 8/2014, 312-319.

[4] R. Jastrzębski, G. Padula, M.Cenin, B.Yalikilicli, P. Brindel, „Możliwości zastosowa-

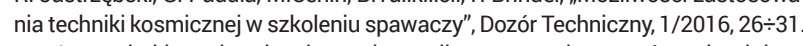

[5] R. Jastrzębski, Robotyka i mechatronika spawania stopów aluminium,

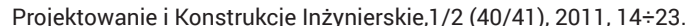

[6] [6] I. Jastrzębska, J. Szczerba, P. Stoch, R. Prorok, E. Śnieżek, Wpływ rodzaju masy otulinowej na właściwości fizykochemiczne żużla oraz technikę spawania, Biuletyn Instytutu Spawalnictwa, 1/2015, 46-52.
[7] I. Jastrzębska, J. Szczerba, Paweł Stoch, R. Prorok, E. Śnieżek, Surowce do produkcji elektrod i drutów proszkowych oraz ich wpływ na właściwości żużla i technikę spawania, 56. Konferencja Spawalnicza Spawalnictwo - zawsze można więcej, 14-16.10.2014, Sosnowiec. http://www.konferencja. is.gliwice.pl/galeria/56_ks/postery/3.pdf

[8] I. Jastrzębska, J. Szczerba, Paweł Stoch, R. Prorok, E. Śnieżek, Review of the raw materials for the production of electrodes and flux-cored wires in terms of their influence on the slag properties and welding technique, 20as Jornadas Técnicas de Soldadura y Tecnologías de Unión, 01-03.10.2014, Madryt, Hiszpania. http://www.cesol.es/nuevaWeb/20jornadas/images/2\%20circular.pdf

[9] Welding Journal, Section News, 2/3, 2016, 83 $\div 84$. http://www.nxtbook.com/ nxtbooks/aws/wj_201602/\#/86 